\title{
Communities in control? The challenges of neighbourhood governance with reference to local government reform in England
}

\author{
Commonwealth Journal of Local Governance \\ Issue 1 May 2008 \\ http://epress.lib.uts.edu.au/ojs/index.php/cjlg
}

\author{
Harriet Churchill ${ }^{1}$ \\ University of Manchester
}

\begin{abstract}
Recent local government and public service reforms in England have been orientated towards devolving public service delivery and decision-making to the neighbourhood level. These reforms have been driven by political, social and managerial agendas that aim to make local government more accountable and responsive to local communities, to build social capital and to enhance the cost-effectiveness of local services. This paper, with reference to the current policy framework in England, aims to identify and review the possibilities and challenges for local government officials and partner agencies in moving towards decentralised public service provision and governance. The paper initially identifies the key aspects of reform brought in by the central government Department of Communities and Local Government that seek to extend neighbourhood influence and governance structures. The discussion then turns towards considering the challenges in ensuring effective citizen participation - namely responding to multiple policy objectives; devising appropriate neighbourhood governance structures; re-thinking the role of local government; identifying and managing trade-offs; building community and local government capabilities for wide-ranging participation; and ensuring effective partnership working at all levels of local government. In conclusion the important steps towards tackling these challenges in England are recognised although a number of concerns remain.
\end{abstract}

\footnotetext{
1 The author wishes to thank two anonymous referees, the journal editor and Liz Richardson of the University of Manchester for their thoughtful and constructive comments on earlier versions of this paper.
} 


\section{Introduction}

Moves to establish devolved and participative forms of governance have been witnessed across many countries in recent years (Stoker, 2006). In England local government and public service reforms have been orientated towards extending neighbourhood level devolution and participation, with claims of a 'new era of shifting power to our communities' (Kelly 2006) and new neighbourhood governance structures that will "forge more influence, control and ownership by local people of local services" (Department of Communities and Local Government [DCLG] 2008:1). The emphasis on decentralisation is further apparent within public service reform proposals set out by all three of the major political parties in England, and is likely to be a prominent issue in the next general election, cast as a fundamental conflict between 'outdated and ineffective old ways of governing' and the necessity for new ways of governing; that is between top-down hierarchical forms of governance and bottom-up, participatory, inclusive decision-making (Blears, 2008).

However, local authorities (LAs) and public service agencies face a huge task in responding to these agendas and realising the positive outcomes that effective citizen participation can engender. This paper, with reference to the development of neighbourhood participative governance in England, aims to identify and review the possibilities and challenges for local government officials and partner agencies in moving towards decentralised public service provision and governance. The paper begins with a review of the legislative framework for neighbourhood governance in England before examining the rationales, opportunities, challenges and options informing local developments on the ground.

\section{Bringing devolution to the doorstep: recent local government and public service reform in England}

Since coming to office in 1997 New Labour has pursued an agenda of modernising public services and revitalising democratic structures. Local government has been criticised for being unresponsive to local needs, unrepresentative of local communities and paternalistic towards service users (Blair 1998). In response, a series of reforms have emphasised "a shift away from representative democracy towards partnership and participatory decision-making" (Daly and Davis 2002: 97). In the 1998 White Paper Modern local government: In touch with people, New Labour set out the need for decisions about local public services to be based on local needs and concerns rather than "what suits the council as a service 
provider" (DETR 1998: i). The introduction of Best Value ${ }^{2}$ duties for LAs, following the 1999 Local Government Act, emphasised partnership working and citizen involvement in public service contracts. LAs have been encouraged to generate new opportunities for citizen participation through the use of citizen consultation, citizen panels, service user groups and e-government initiatives (Daly and Davis 2002). Reforms within housing, social care, education, health and crime prevention have involved institutional reform towards establishing multi-agency partnerships as the vehicle through which local service priorities are set and professionals work together to better coordinate and integrate services.

For example, from 1999 the Sure Start initiative, an early intervention program aimed at families with younger children in neighbourhoods classed as multiply deprived, has involved the establishment of local partnerships whereby professionals delivering services to these families work together to provide an integrated package of services within a specific locality. Sure Start Partnerships from the outset were to work with parents and communities in 'new ways being involving, transparent, nonstigmatising and inclusive' (Williams and Churchill 2006). Reforms in housing have involved an emphasis on tenant participation with the establishment of local housing tenants' management boards (Daly and Davies 2002). Crime prevention and health promotion initiatives have also led to local partnerships, which seek to include community representatives and local citizens in order to be responsive to local concerns.

Alongside the expansion of local service delivery and consultative partnerships that seek to involve communities as well as a range of service providers and interest groups, local government reform progressed towards establishing strategic partnerships at a more executive level with the aim of improving overall strategic planning and coordination. The 2000 Local Government Act called for LAs to produce a Community Plan and detail a comprehensive, coordinated plan for social, economic and environmental wellbeing across areas and communities. Many LAs at this point set up a council-wide Local Strategic Partnership (LSP), made up of senior representatives of local service providers, as the overall strategic body to produce and oversee the implementation of the Community Plan.

In 2006, the White Paper Strong and Prosperous Communities brought a new chapter to local government reform in England (DCLG 2006) and led to the 2007 Local Government and Public Involvement in Health Act. The White Paper sought to further re-fashion the leadership role of local government, to strengthen strategic and outward-looking partnership

\footnotetext{
2 The Best Value system was introduced in 1998 as a new framework to guide service contract and delivery decisions for local government services. It aims to improve the quality of local public services via an inspection and audit system that assesses the costeffectiveness and performance of service providers against locally agreed objectives.
} 
working and, crucially for this paper, further decentralise local decisionmaking and service delivery/management. With concern for local democracy and accountability, the White Paper put forward radical proposals to allow LAs to choose between three types of executive models - to have a directly elected mayor, a directly elected executive or an indirectly elected executive. ${ }^{3}$

In line with previous reforms, the White Paper sought to strengthen the shift from an input-based approach to public service reform towards an outcome-based approach whereby LAs and partner agencies are given more scope and responsibility to set local priorities, decide on how to best to meet local needs, and improve local services within an agreed framework of service outcomes. The White Paper also upheld the view that multiagency partnerships were the key mechanism by which local priorities were set and decisions about funding allocations were made (Glendinning et al 2002). However, the White Paper claimed there was a need to clarify central-local accountability by strengthening the leadership role of LAs and simplifying the system of central-local performance management. From late 2007, LSPs are to produce and agree with central government a Local Area Agreement (LAA) whereby 25-35 outcome-based targets would be set out covering four thematic areas of service provision - children and young people, healthier communities and older people, economic development and the environment, and safer and stronger communities.

Two other local frameworks will be significant in steering the work of the LSP and contributing to the LAA - the Sustainable Communities Strategy and the Local Development Framework. ${ }^{4}$ A strong leadership role is envisaged for LAs with senior statutory representatives expected to play a major role in LSPs. The White Paper additionally placed a duty on partner agencies to cooperate with the LA, collaborate in establishing local priorities and work towards meeting the targets agreed in the LAA.

The White Paper was also concerned with establishing new neighbourhood governance structures for citizens to 'shape policies, services and places'. More effective community involvement was viewed as important in ensuring that services are designed around the needs of citizens and communities and "not processes and structures of individual agencies" (Blears 2008:1). Several measures aimed to enhance opportunities for community engagement while other aspects of reform aimed to strengthen accountability to citizens. LAs were encouraged to more extensively

\footnotetext{
${ }^{3}$ The executive is the 'cabinet' of senior councillors that oversee day-to-day decisionmaking and management. A directly elected executive involves political parties and individuals standing for senior positions in open local elections and holding office for a fixed term. An indirectly elected executive is selected from amongst the councillors. ${ }^{4}$ The Sustainable Communities Strategy and the Local Development Framework are strategic plans setting out the local 'place vision' and local objectives for economic and social development in line with central government guidance.
} 
establish neighbourhood governance structures such as Town or Parish Councils. Funds were announced for community-led social enterprise and asset management schemes such as community ownership of unused local buildings. Local councillors have seen their role re-defined as 'democratic champions' with a small budget provided to councillors for citizen-led community development. The influence of neighbourhoods is to be further enhanced by more use of tools such as Local Charters and Community Calls for Action. Local Charters, perhaps devised by Town and Parish Councils, are envisaged as a way of setting out service standards, local priorities and the relative responsibilities of LAs, agencies and local communities through a process of dialogue and deliberation. Community Calls for Action were described in the White Paper as a new mechanism whereby local councillors can call for action from the LA, and to which the LA executive are expected to respond within a given timeframe. The Best Value regime has also been reformed so that a greater onus is placed on LAs and service providers to 'inform, consult and devolve to local citizens and communities' as part of their public service agreements.

Two further recent developments will contribute to the expansion of neighbourhood and participatory governance in England. Firstly, in 2008 Hazel Blears, the Secretary for Communities and Local Government, announced an imminent White Paper on Community Empowerment. Blears stated that the White Paper will seek "to give people a real say in public services" and "put communities in control" (Blears, 2008:1). The White Paper will build on proposals set out in the Community Empowerment Action Plan, published in October 2007. In this plan the Department of Communities and Local Government indicated support for more community management and participatory budget schemes ${ }^{5}$, greater use of local petitions in calling for local authority and government action, an active role for Parish Councils, and more transparency and openness among service providers.

Secondly, a further significant legislative development has been the Sustainable Communities Act 2007. This Act began as a private members' bill brought forward by campaigners who felt the 2006 Local Government White Paper did not go far enough in radically altering the balance of power between the state and citizens. As a consequence the Act has placed a legal duty on LAs to establish citizen panels, representative bodies of local citizens, which are to have the role of contributing to setting out local priorities and scrutinising local policies. LAs have a duty to take action on the suggestions put forward by the citizens' panels.

\footnotetext{
${ }^{5}$ These schemes involve local community members being directly involved in the planning, management and delivery of local community services, such as community collectives bidding to refurbish a vacant local building and use the refurbished building for community groups and events.
} 


\section{Devolution and decentralisation: rationales and opportunities}

The legislative changes set out above significantly extend neighbourhood and participatory governance structures and relationships in England; and are driven by three overarching rationales which relate to democratic/civic, social and managerial concerns and objectives (DWP 2006; DfES 2004;

SEU 2004; NRU 2002; ODPM 2005; Home Office 2003).

\section{Democratic and civic rationales}

Evidence of declining voter turn-out at elections, extremist party recruitment and dwindling party membership raise fundamental concerns about the democratic legitimacy of the policy process. Other changes, such as the shift towards multi-actor and multi-level governance processes and the recognition of the multi-faceted complexity of contemporary social problems that stretch beyond national boundaries and centrally organised departments, also have implications for the health of democracy as policy processes become increasingly complex and extend beyond party politics and civil servant departments (Bovaird and Lofler 2003; Pollitt and Bouckaert 2004; Pollitt and Talbot 2004). Citizen demands, issue-based campaigns, internet-facilitated political participation and diversified media coverage generate and sustain an awareness of unsolved social problems, high expectations and political activity beyond the party political arena (Stoker 2006).

Enhancing opportunities for community involvement in the policy process has become a critical step towards strengthening citizen-government relations in this context. The forms of participation can vary considerably from simply receiving up-to-date information about government activities, to consultation, active participation and even community-led service delivery, such as in the case of a community owned local facility (Bingham et al 2005). Involvement can be short-lived, focused on a specific local initiative, or involve input to debates on complex social problems affecting a range of service providers and community members (Lowndes and Sullivan 2006). Encouraging effective and responsive community involvement activities can strengthen democratic processes in a variety of ways:

- Citizens and government begin to engage more in a personal and meaningful way which can generate a two-way learning process towards a more aware and active citizenship, and better informed and more responsive government actors (Corry et al 2004; Lowndes and Sullivan 2006);

- Citizens become better equipped and more able with knowledge, awareness and real life contact with officials, to hold governments to account (Stoker 2006); 
- Citizens feel they have a stake in governance with opportunities to express their views and affect policy decisions (Perri 6 et al 2002);

- A more informed and involved citizenship within a more responsive local governance system is more likely to generate consensus, shared ownership and compliance voluntarily for policy decisions (OECD 2001; Corry et al 2004);

- Hence community participation can enhance accountability, rebuild trust, regenerate democratic legitimacy and encourage responsive policy-making - supplementing and strengthening the representative democratic system (Lowndes and Sullivan 2006; Stoker 2006).

\section{Social rationales}

The more social arguments for community participation focus on the close connections between community involvement, social capital, social regeneration, human wellbeing and self-worth. While social networks and identities stretch beyond those operating within spatially defined neighbourhoods, community involvement in and of itself can lead to personal and community development outcomes:

- Community relations can be strengthened, collective identities formed, reciprocal friendships made, and divisions between social/family groups lessened (Beattie et al 2004);

- Being involved in shaping and caring about your community can of itself boost social inclusion, a sense of belonging and selfworth/purpose (Almedom 2005);

- In areas where such community activity and relationships are already well furnished, local agencies can offer more concrete opportunities for sharing and utilising resources and expertise, widening the net for recruiting neighbourhood leaders and further creating opportunities for social bonding within groups and bridging across groups (OECD 2001; DfES 2004).

\section{Managerial rationales}

Research recently conducted concluded that while there is a high level of community support for public services in the UK, people were critical of local councils for not providing enough information and a lack of transparency and honesty in decision-making, as well as being concerned about the quality of some services (Audit Commission 2003). Community involvement, if done well, can help regain lost trust and has also been closely tied to service efficiency and effectiveness gains. While centrally designed and standardised services are appropriate for some functions such as welfare benefit distribution, others such as the delivery of police, health or education services need to be appropriate to local problems and conditions (Corry et al 2004). Here, the input of local citizens as well as other stakeholders is crucial in order to fit interventions with local problems 
and needs - in effect minimising costly policy failure (Lowndes and Sullivan 2006; Perri 6 et al 2002). Citizen participation, therefore, can be about better policy making:

- Citizens add a unique role and resource to the policy process as experts on their own problems, needs and experiences. Their input can lead to a more holistic and grounded view of an issue or set of needs, and hence a better knowledge base for policy making and review, minimising the risks of policy failure (Corry et al 2004; OECD 2001);

- Citizens can have input across the spectrum of the policy process ranging from debating social problems to policy planning, drafting, implementation and evaluation (OECD 2001).

Hence the 2007 Comprehensive Spending Review in England (HM Treasury 2007) included expectations for efficiency gains to be realised through the implementation of the reforms to partnership working and the Best Value regime as set out in the 2006 White Paper.

These rationales, however, are far from contested and are contingent on effective, fair and representative neighbourhood governance activities. Rather than renew citizens' confidence in government institutions and build community cohesion, citizen participation initiatives can have negative outcomes if participation is tokenistic, unduly complex, duplicates workloads, mystifies accountability, or is co-opted by the most vocal, organised and 'networked' local individuals and groups. It is individuals and groups with higher levels of social, cultural and economic capital that engage in more formal types of community engagement and hence, there is much concern that New Labour's 'decentralised Britain' in practice means 'big remote centralised empires' are broken up into 'municipal based little empires' (Corry et al 2004). Such developments compound rather than reduce social exclusion, democratic deficits and inequalities. Generating support for community involvement initiatives requires a pro-active approach to tackling such inequities. The requirement for Citizen Panels to be representative of the local population and social groups is a step in the right direction - but much will need to be done to enable people to participate and generate local confidence in the process.

Furthermore, it is not necessarily the case that community engagement in decision-making will make for more efficient decision-making. Effectively devolving decision-making and scrutiny functions to the neighbourhood level will require the active investment of financial and human resources, with high transaction costs in the short-term - albeit with the potential of significant savings in the long-run if decision-making reduces ineffective and contested policy designs (OECD 2001). The claim that citizen participation will enhance the responsiveness of services is equally 
contentious. There is little recognition in the official policy documents reviewed above that a responsive service could mean a variety of things to different service users, and that neighbourhoods are far from homogenous entities. While there is considerable consensus over some issues, such as the deserving claims of children to social protection, education, health and welfare, other issues can raise considerable conflict, as in the case of criminal justice policies. Recent research has also questioned the degree to which individuals taking part in community participation activities can be said to represent community interests, or whether they merely pursue their own self interests (Daly and Davies 2002). Likewise research has highlighted the anxiety among community members when asked to 'speak for their neighbourhood' or make important service priority decisions (Daly and Davies 2002; Skidmore et al 2006).

A recent review of people's experiences in devolved decision-making indicated the need to focus on appropriate issues. For example, decisions about local recycling services were perceived as far more suitable for devolution and likely to be enhanced by neighbourhood involvement, whereas being asked to make decisions about education, health or social care services caused anxiety as people felt they were rationing services without adequate knowledge of needs (Ipsos/MORI 2007). Research into Citizens Panels undertaken by Ipsos and MORI claimed there were two rationales for limiting decentralised decision-making when it comes to education, health and social care services. Firstly, there appears to be a strong consensus in support of the primary role of professionals in allocating and administering quality local services. Secondly, some community members held discriminatory attitudes towards marginalized groups (Ipsos/MORI 2007). Further, the more deliberative and participatory neighbourhood governance initiatives become, a (healthy) increase in debate and disagreement is likely to occur - but who is to broker the situation? Will a consensus be required? Whose interests will prevail?

In England a strong leadership role for statutory agencies has been emphasised but it is exactly these agencies that neighbourhoods and communities will be seeking to influence, hold to account and make more responsive. Recent community consultation activities undertaken by government officials which involved presenting citizens with 'the evidence' for and against a decision were heavily criticised for bias and providing misleading information (Ipsos/MORI2007). Meanwhile, the role of ward councillors has been re-fashioned as one of community leadership, but this has raised issues around the difficulties of recruiting councillors and the unrepresentativeness of ward councillors in terms of their background - they tend to be drawn from groups considered the 'local elite' or individuals with higher levels of education. It is unclear how 
councillors will respond to this new leadership role and whether a wider cross section of the population can be recruited.

\section{Developing effective citizen participation}

The evidence suggests that ineffective, symbolic and tokenistic neighbourhood participation in decision-making can be as dangerous to democracy as the often unrepresentative and centralised status quo. The remainder of this paper seeks to contribute to the development of effective citizen participation initiatives by reviewing the opportunities, challenges, options and issues for local officials seeking to generate meaningful participation. In responding to the current legislative framework and concerns about effective implementation, the discussion below considers six key issues for local officials:

- Defining good neighbourhood governance

- Choosing neighbourhood governance institutional arrangements 'fit for purpose'

- Defining the role and responsibilities of local government within the new neighbourhood governance arrangements

- Investing in capacity building

- Encouraging joined-up partnership working

- Managing trade-offs.

\section{Notions of good neighbourhood governance}

Local authorities are well placed to engender and model principles of good neighbourhood governance. Corry et al (2004) set out six key principles that need to equally inform neighbourhood governance initiatives and structures. These are:

- Effectiveness: 'The ability to get things done'

- Accountability: 'Providing clear accountability'

- Participation: 'Promoting participation and involvement'

- Equity: 'Being capable of delivering equity'

- Diversity: 'Recognising and underpinning diversity'

- Innovation: 'Encouraging innovation and the evolution of services in line with citizen desires'.

Lowndes et al (2006) devised a framework for effective citizen participation based on their research into citizens' experiences and perspectives. They argue that participation is most effective where citizens:

Can do - they have the resources and knowledge to participate

Like to - they have a sense of attachment furnishing participation Enabled to - are provided with opportunities and support for participation 
Asked to - they are asked to participate by official bodies and local agencies

Responded to - they see evidence that their views have been considered.

\section{The search for appropriate institutional arrangements}

There is evidence that different types of neighbourhood institutions are suited to different objectives. A range of challenges therefore face local agencies in developing institutions and tools for participation that are suited to specific political, social or managerial objectives. Lowndes and Sullivan (2006) have provided a useful typology of four ideal types of neighbourhood governance institutions linked to different rationales and objectives: neighbourhood empowerment, partnership, government and management.

Table 1: The four ideal types of neighbour governance institutions

\begin{tabular}{|c|c|c|c|c|}
\hline & $\begin{array}{l}\text { Neighbourhood } \\
\text { Empowerment }\end{array}$ & $\begin{array}{l}\text { Neighbourhood } \\
\text { Partnership }\end{array}$ & $\begin{array}{l}\text { Neighbourhood } \\
\text { Government }\end{array}$ & $\begin{array}{l}\text { Neighbourhood } \\
\text { Management }\end{array}$ \\
\hline $\begin{array}{c}\text { Primary } \\
\text { Rationale }\end{array}$ & Civic & Social & Political & Managerial/Economic \\
\hline $\begin{array}{c}\text { Key } \\
\text { Objective }\end{array}$ & $\begin{array}{l}\text { Active citizens } \\
\text { and cohesive } \\
\text { communities }\end{array}$ & $\begin{array}{c}\text { Citizen } \\
\text { wellbeing and } \\
\text { regeneration }\end{array}$ & $\begin{array}{l}\text { Responsive and } \\
\text { accountable } \\
\text { decision-making }\end{array}$ & $\begin{array}{l}\text { More effective local } \\
\text { service delivery }\end{array}$ \\
\hline $\begin{array}{c}\text { Democratic } \\
\text { Device }\end{array}$ & $\begin{array}{l}\text { Participatory } \\
\text { democracy }\end{array}$ & $\begin{array}{l}\text { Stakeholder } \\
\text { democracy }\end{array}$ & $\begin{array}{c}\text { Representative } \\
\text { democracy }\end{array}$ & Market democracy \\
\hline $\begin{array}{c}\text { Citizen } \\
\text { Role }\end{array}$ & Citizen: voice & Partner: loyalty & Elector: vote & Consumer: choice \\
\hline $\begin{array}{l}\text { Leadership } \\
\text { Role }\end{array}$ & Amateur, enable & Broker, chair & $\begin{array}{l}\text { Councillor, } \\
\text { mayor }\end{array}$ & $\begin{array}{l}\text { Entrepreneur, } \\
\text { director }\end{array}$ \\
\hline $\begin{array}{l}\text { Institutional } \\
\text { Forms }\end{array}$ & $\begin{array}{l}\text { Forums, co- } \\
\text { production of } \\
\text { services }\end{array}$ & $\begin{array}{l}\text { Service board/ } \\
\text { partnership, } \\
\text { local service } \\
\text { agreements }\end{array}$ & $\begin{array}{l}\text { Town councils, } \\
\text { area committees }\end{array}$ & $\begin{array}{l}\text { Contracts and } \\
\text { charters }\end{array}$ \\
\hline
\end{tabular}

Source: Lowndes and Sullivan 2006

Neighbourhood empowerment models seek to maximise citizen opportunities and capacities for effective participation in decisionmaking and/or service delivery. A crucial aspect of this objective is that there needs to be real and concrete shifts in power from government and managers to citizens, so that citizens really have a say in policy decisions. Government has to give up exclusive control over policy content and dialogue - although the final decision clearly remains with it (Diamond 2004; Pearce et al 2004). Local authorities have a clear role to empower citizens - to mobilise, facilitate, support and respond to citizen participation through capacity building, participation opportunities, and transparency and responsiveness.

Neighbourhood partnership aims to gain a holistic view of citizens' needs in relation to service development. Partnerships 
have been central to the development of complex service areas, such as health promotion, crime prevention, family support or child poverty, that require all stakeholders to be involved in a process of collective decision-making in order to enhance effectiveness. Partners represent different organisations or communities, with different mandates, historical involvement and structural power positions. Interests are brought together by the partnership chair.

Neighbourhood government is about extending openness and representation to and from the neighbourhood level in order to reestablish democratic accountability. The idea of elected neighbourhood representatives is key. These representatives may have functions within a particular service area, joined-up service delivery or across the neighbourhood as a whole. The elected individual represents the community to the local authority, scrutinising the work of the LA as an advocate of the community, rather than representing a committee or party in local government. The aim is to extend and supplement current forms of representation to connect existing structures and activities to the local level (Corry et al 2004).

Neighbourhood management seeks to empower local service managers to deliver services in line with citizens' needs and preferences. The aim is to enhance manager-citizen communication and citizen choice so that services can run more efficiently and effectively at the local level. Options can include devolving budgets, re-locating service operations, commissioning local market research and devolving many aspects of service decision-making down to the neighbourhood level. 


\section{Principles for neighbourhood arrangements}

The UK government discussion paper Citizen Engagement and Public Services: Why Neighbourhoods Matter (ODPM and Home Office 2005) talks about a 'framework for neighbourhoods' as the foundation for a neighbourhood charter. The framework would consist of a national framework statement setting out the principles for neighbourhood arrangements, together with an undertaking by government, local authorities and others to adopt measures to resource and build capacity for neighbourhood engagement. The five key principles to be applied are that:

- councils and service providers provide opportunities and support for neighbourhood engagement;

- neighbourhood arrangements must be capable of making a real difference to citizens' everyday lives;

- neighbourhood arrangements must be appropriate to local circumstances, flexible to changing circumstances and responsive to local needs and the diversity of the community and its organisations;

- neighbourhood arrangements must be consistent with local representative democracy;

- neighbourhood arrangements must be balanced with the demands for efficiency and proportionality.

These principles give plenty of scope to establish arrangements appropriate to local needs. Hilder (2005) suggests that within the broad range of institutional structures and arrangements that may be chosen for different localities, there are some key elements that "need to work together if neighbourhood arrangements are to deliver practical rewards and improve quality of life." These are shown in Figure 1 below and include:

- Legitimacy - political authority grounded in a clear mandate from electors

- Identification - the extent to which people feel a sense of belonging and common challenges, identifying with the area defined as a neighbourhood and concerned about its issues

- Effectiveness - mechanisms for improving public services and the local public realm

- Partnership - the practical process by which a variety of authorities, organisations and individuals works together to make a difference. 


\section{Local government tiers of decision-making}

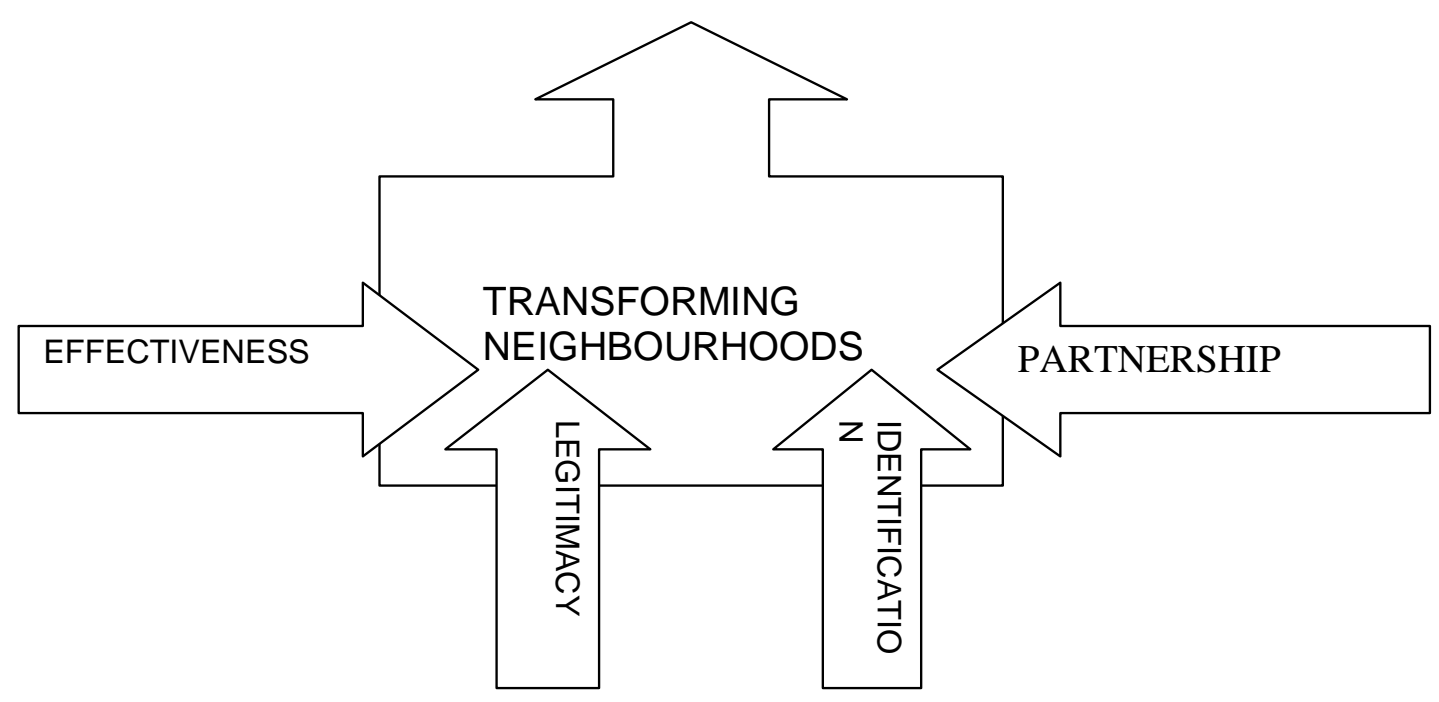

Figure 1: Dynamics for neighbourhood arrangements (Hilder, 2005)

In the same paper by the Young Foundation (Hilder 2005), there are also some headline recommendations:

- The policy design needs to combine rights and powers with neighbourhood capacity building and public authority change agendas.

- Neighbourhoods should have the opportunity for considerable power in a limited range of core areas dictated by subsidiarity, focused where there are likely to be few negative externalities.

- Neighbourhoods should have some budget power, and the flexibility to win further powers in time.

- Where there is clear demand for a formal neighbourhood structure, it should be easy for citizens to establish it - disestablishment should be equally easy provided there is broad support.

- A variety of arrangements should be available dependent on context - processes and outcomes matter most.

- Ward councillors should have the chance to lead, but not a general right to block (meaning that they should be empowered to play a leading role in neighbourhoods, but not given a direct veto over all neighbourhood initiatives or arrangements).

- Public authorities need to tackle administrative barriers that may frustrate neighbourhood working, from constraints around Local Area Agreements to the paucity of neighbourhood data; as well as decide on whether improvements in services are best met by needs- 
based authority wide interventions or neighbourhood level planning.

These suggestions indicate the need to consider the multiple ways that neighbourhoods can be more involved in local decision-making and to establish stronger mechanisms by which neighbourhoods can hold local agencies to account.

\section{The re-orientation of local authority roles}

The decentralisation of collective decision-making and/or service delivery involves a strong role for LAs as enablers of community 'voice and choice' as: brokers of interests; overseers of the principles and standards for good governance; and, coordinators of a multi-actor and multi-level system of governance. The earlier points raised in relation to developing the principles of good governance are relevant here, and we will now further examine the tasks of managing trade-offs and tensions between good governance principles, capacity building and joining up services. The paper then concludes by identifying a strategic way forward for local leaders.

\section{Managing trade-offs}

The wider literature in this area discusses a number of common tensions in developing neighbourhood governance in line with the political, social and economic rationales above. These can be characterised as: consultation versus influence; access versus competence; cohesion versus pluralism; and choice versus equity.

Consultation and influence: Citizen participation can be described in terms of a spectrum of participation ranging from being consulted (having a say about your service needs or public service preferences) to meaningful influence and participation (having a significant influence in decision-making at the strategic level). Cynical views about citizen participation can arise when consultation leads to very little change at the level of strategic decision-making or front-line public service delivery. However, both consultation and more meaningful participation can be highly valued and different types of participation are appropriate for different types of decisions. Evidence suggests that citizens highly value being heard, listened to, consulted and respected for their contribution to the policy process, and are capable of grasping the bigger picture of governmental resource allocation and prioritisation (MORI/Audit Commission 2003). Citizens have emphasised that being consulted and having your views respected and taken into consideration are important to them as well as having an influence in the decision-making process. Citizens say 
they want leaders that are honest, trustworthy, communicative and competent, who treat people well, are interested in their views and keep their promises (MORI/Audit Commission 2003). Ethnic minorities and young people are examples of groups that tend to feel they are not treated with respect or fairly - views that can change following positive experiences of 'being heard' even if services are not altered radically (MORI/Audit Commission 2003; Curtis et al 2004).

A vital task here is for local agencies to be clear and communicative about the objectives of involvement and the scope of citizen influence and decision-making capacity. Therefore blends of neighbourhood empowerment with neighbourhood partnership and management are useful - a mixture of civic education, involvement, consultation, redress and participation. Clear responsibilities and appropriate institutional arrangements will need to be applied to specific areas of service delivery or more generic coordination, consultation or guidance functions across services (OECD 2001). In the English case, the introduction of a Community Call for Action and the strengthening of the ward councillor's right to call for action will be vital mechanisms through which communities could hold government agencies and service providers to account.

Access and competence: This is a tension between the need for inclusive and representative participation and the need for competent, respectful and responsible citizen involvement. Whereas some neighbourhoods and individuals have a strong tradition of neighbourhood involvement, others will not. Broader citizen involvement means moving beyond the engagement of well- organised individuals. Here it is important to offer a range of participation options, build people's capacities, and engage in creative forms of community consultation and market research to find out citizens' interests, to harness the commitment of community minded people, and to find ways of resourcing and expanding capacity building activities. Mechanisms for sustaining community involvement can include ensuring any neighbourhood representative involved in local service or strategic partnerships only stands for a limited period; and that representatives are sought from a range of local community groups and populations. Again it is about harnessing the competences and capacities that citizens can contribute and joining these up with existing managerial, political and professional expertise.

Cohesion and pluralism: This tension involves a concern that small neighbourhood units for governance can exacerbate 
boundaries and divisions that feed into exclusionary or elitist community relations. 'Strong communities' can also be insular ones, unwelcoming of change and diversity, as they may be founded on close-knit family bonds or social networks based on similar backgrounds or identities. Not only are smaller community units more likely to be less diverse, but group dynamics can become dominated by particular individuals, and the personal nature of relationships can reinforce boundaries between cliques, favourites, friends and outsiders.

Thus neighbourhood units can be poor at establishing links between communities and across distinct personal relationships (Lowndes and Sullivan 2006). Here a clear role exists for LAs to open up more tightly-knit areas and encourage a welcoming approach to newcomers or outsiders. The management of community relationships may involve training on respect for diverse lifestyles or resources for encouraging sharing information and experiences across communities and neighbourhoods. The LA will need to develop mechanisms for non-discriminatory practice using awareness training, modelling and rewarding 'good' behaviour, advocating for minority groups and addressing incidents of discrimination.

Choice and equity: This tension expresses a concern that devolution of public services leads to differences in forms of delivery - and more worryingly in the standards and levels of services. At worst we could have a 'postcode' lottery of differential standards in services depending on where you live (Lowndes and Sullivan 2006). Central and local governments have a key role to play in ensuring this is not the case and that poorer or disadvantaged neighbourhoods do not become ghettos of poor provision because of a lack of voice, capacity or choice for community governance.

\section{Capacity building}

Capacity building relates to a number of issues: the capacities of local officials and departments, as well as the capacities of citizens to engage in neighbourhood governance. Local agencies need to facilitate conditions that furnish effective neighbourhood governance. Ongoing developments now include citizenship education, community participation training, user perspective training and identifying barriers to participation on both sides. New competencies, ethics and attitudes need to be nurtured, harnessed and modelled. Training for local officials in managing community relationships, user perspective awareness and community development approaches has proved useful in some councils (ODPM 2005). 


\section{Joining-Up}

Concerns often aired about decentralised decision-making and service delivery relate to the generation of complex, overlapping and competitive service domains. Joining-up service activities and developments both across sectors and between the various tiers of organisational and governmental hierarchies has therefore been a long-standing issue. Central and local governments have a vital role in determining which service areas require a joined-up approach and providing the mechanisms and incentives for vertical and horizontal integration. Vertical integration refers to the different functional departments in an organisation with shared objectives, resources and outputs, whereas horizontal integration refers to individuals and organisations across services sectors or constituencies. Extending neighbourhood governance involves thinking through where sectors and organisations depend on one another and require a joined-up approach. Encouraging common perspectives around shared outcomes, a clear line of accountability to the LA, an ethos of public service, appropriate rewards and obligations, and transparent decision-making will all contribute towards joined-up working (Corry et al, 2004)

\section{Conclusion}

This paper has reflected on the opportunities and challenges associated with devolved and decentralised decision-making in relation to public services and neighbourhood renewal with reference to recent policy developments in England. The paper has identified a series of challenges that face local agencies in ensuring that the moves towards neighbourhood involvement in reforming public services really does 'forge more influence, control and ownership by local people'. These challenges include:

- working across the political, social and managerial agendas driving devolution initiatives;

- establishing the appropriate neighbourhood level institutional structures;

- investing in engaging all sectors of local communities;

- ensuring public services offer choice, responsiveness and equity;

- devising a range of citizen participation opportunities; and,

- providing local neighbourhoods with meaningful influence and accountability mechanisms.

Where LAs and partner local agencies are motivated to engage and involve neighbourhoods and communities to a significant extent, recent local government reforms in England provide opportunities for important structural changes. For example, the move towards more directly elected local leaders and executive members all offer much scope for strengthening local democracy and neighbourhood influence, including:

- more opportunities for neighbourhood involvement in local priority setting and service planning; 
- embedding service user perspectives into the system of performance monitoring and service provider contract allocation; and

- a strengthening of the powers and role of local councillors as representatives of local neighbourhoods

However, with efficiency savings expected as part of these reforms, and limited powers for neighbourhoods to influence the highest levels of strategic decision-making in LAs, there appears to be insufficient recognition from central government of the need to invest hugely in building a representative and inclusive programme of citizen involvement; protecting marginalized or vulnerable service users from discriminatory attitudes; ensuring local equity of service provision alongside local responsiveness; and significantly reforming the checks and balances ensuring LAs and public service providers are directly accountable to local citizens and services users.

\section{References}

Almedom, A (2005) 'Social Capital and Mental Health: An Interdisciplinary Review of Primary Evidence', Social Science and Medicine, 61, 5, pp.943-964.

Beattie, R.S., Osborne, S and Williamson, P.A (2004) 'Addressing fragmentation and social exclusion through community involvement in rural regeneration partnerships: evidence from the Northern Ireland experience', Policy and Politics, 32, 3, pp.351-369.

Bingham, L.B., Nabatchi, T, O’Leary, R (2005) The New Governance: practices and processes of stakeholder and citizen participation in the work of the government, Public Administration Review, 65, 5, pp.547-558.

Birchall, R.J and Simmons, R.A. (2002) A Theoretical Model of What Motivates Public Services Users to Participate, London: ESRC.

Blair, T (1998) Leading the way: A new vision for local government, London: Institute for Public Policy Research.

Blears, H (2008) Five years from now, Speech to the LGC Community Engagement Conference, $19^{\text {th }}$ March 2008, London: Royal Horticultural Halls.

Bovaird, T and Lofler, E (eds) (2003) Public Management and Governance, London: Routledge.

Burns, D (2000) 'Practices for Citizenship', Community, Work and Family, 3, 3, pp.261-77.

Clare, L and Cox, S (2003) 'Improving service approaches and outcomes for people with complex needs through consultation and involvement', Disability and Society, 18, 7, pp.935-953.

Corry, D., Hatter, W., Parker, I., Randle, A and Stoker, G (2004) Joining Up Local Democracy: Governance systems for New Localism, London: NGLN.

Curtis, K., Liabo, K., Roberts, H and Barker, M (2004) 'Consulted but not heard', Health Expectations, 7, 2, pp.149-156.

Daly, G and Davies, H (2002) 'Partnerships for local governance: citizens, 
communities and accountability', in Glendinning, C., Powell, M and Rummery, K (eds) Partnerships, New Labour and the Governance of Welfare, Policy Press, Bristol.

Department of Communities and Local Government (DCLG) (2006) Strong and prosperous communities, Local Government White Paper, London: HMSO.

DCLG (2008) Unlocking the talent of our communities, Leeds: Communities and Local Government Publications.

Department of Education and Skills (DfES) (2004) Ten Year Childcare Strategy, London: HMSO.

Department of Work and Pensions (DWP) (2006) Empowering People To Work, London: HMSO.

Department of the Environment, Transport and the Regions (DETR) (1998) Modern local government: In touch with the people, Cm 4014, London: TSO.

Diamond, J (2004) 'Local Regeneration Initiatives and Capacity Building: Whose 'Capacity' and 'Building' for What?', Community Development Journal, 2004, 39, 2, pp.177-189.

Evans, M., Eyre, J., Millar, J and Sarre, S (2003) New Deal for Lone Parents: Second Synthesis Report for the National Evaluation, London: HMSO.

Fawcett, B and South, J (2005) 'Community Involvement and Primary Care Trusts: The Case for Social Entrepreneurship', Critical Public Health, 2005, 15, 2, pp.191-204.

Ghate, D and Hazel, N (2002), Parenting in Poor Environments: Stress, Support and Coping, London: Jessica Kingsley.

Glendinning, C., Powell, M and Rummery, K (eds) (2002) Partnerships, New Labour and the Governance of Welfare, Policy Press, Bristol.

Hilder, P. (2005) Seeing the wood for trees: the evolving landscape for neighbourhood arrangements, London: Young Foundation.

Home Office (2003) Home Office Citizenship Survey, London: Stationary Office.

HM Treasury (2007) Meeting the aspirations of the British people: 2007 Pre-Budget Report and Comprehensive Spending Review, Cm 7227, London: HMSO.

Ipsos/ MORI (2007) Public services policy review: The public view, Final report of the Citizens Panels, available at www.mori.com.

Kelly, R (2006) Reform to bring 'devolution to the doorstep', Press release for the Department for Communities and Local Government, 2006/0100, 19th September 2006, accessed at $<</$ www.communities.gov.uk/index.asp?id=1002882\&PressNoticeID=2246>>

MORI/ Audit Commission (2003) Trust in Public Institutions, London: MORI. Myers, P., Barnes, J and Brodie, I (2004) Partnership working in Sure Start Local Programmes, NESS Synthesis Report 1, London: DfES.

Neighbourhood Renewal Unit (2002) Collaboration and Coordination in Area Based Initiatives, London: NRU.

Lowndes, V and Sullivan, H (2006) How Low Can You Go? Neighbourhood Governance and Modernisation, paper for the Political Studies Annual Conference, Reading, April 2006.

Lowndes, V., Pratchett, L and Stoker, G (2002) The Locality Effect: Local 
Government and Citizen Participation, working paper, De Montfort University, Department of Public Policy.

Lupton, R (2004) Poverty Street, Bristol: Polity Press.

Office of the Deputy Prime Minister (2005) New Localism - Citizen Engagement, Neighbourhoods and Public Services: Evidence from Local Government, London: ODPM.

ODPM and Home Office (2005) Citizen Engagement and Public Services: Why Neighbourhoods Matter London: ODPM

OECD (2001) Citizens as Partners: Handbook on information, consultation and public participation, Paris: OECD.

Pearce, G and Mawson, J (2003) 'Delivering Devolved Approaches to Local Governance', Policy and Politics, 2003, 31, 1, pp. 51-67.

Perri 6., Leat, D., Skelzer, K and Stoker, G (2002) Towards Holistic Governance, Basingstoke: Palgrave.

Pollitt, C and Bouckhaert, G (2004) Public Management Reform, Oxford: OUP.

Pollitt, C and Talbot, C (2004) Unbundled Governance, London: Routledge.

Social Exclusion Unit (2004), Tackling Social Exclusion: Progress so far, London: HMSO.

Skidmore, P., Bound, K and Lownsbrough, H (2006) Community Participation: Who benefits? London: DEMOS/JRF.

Stoker, G (2006) Why Politics Matters, Basingstoke: Palgrave.

Williams, C (2005) 'Cultivating Community Self-Help in Deprived Urban Neighborhoods', City \& Community, 2005, 4, 2, pp.171-188.

Williams, F and Churchill, H (2006) Empowering parents in Sure Start Local Programmes, National Evaluation of Sure Start Report, NESS/2006/FR/018, London: DfES. 